\title{
PENGARUH PENAMBAHAN GEL PORANG DAN BAGIAN TELUR TERHADAP KARAKTERISTIK MUFFIN PASTA SINGKONG DAN KEDELAI HITAM
}

\section{The Effect of Porang Gel Addition and Different Egg Parts Usage to Cassava and Black Soybean Paste Muffin Characteristic}

\author{
Delvi Addelia Vriyanie*, Aji Sutrisno \\ Jurusan Teknologi Hasil Pertanian, FTP Universitas Brawijaya Malang \\ JI. Veteran, Malang 65145 \\ *Penulis Korespondensi, E-mail: addeliadelvi@gmail.com
}

\begin{abstract}
ABSTRAK
Penelitian ini bertujuan untuk mengetahui pengaruh penambahan pasta singkong dan kedelai hitam terhadap sifat fisik, kimia, dan organoleptik muffin non terigu. Metode yang digunakan yaitu Rancangan Acak Kelompok Faktorial (RAKF) yang disusun dengan 2 faktor dan 3 kali ulangan. Faktor pertama yaitu pengunaan telur yang berbeda (utuh dan kuning) sedangkan faktor kedua adalah pemberian gel porang $(0 \%, 1 \%, 2 \%, 3 \%)$. Data dianalisis menggunakan ANOVA ( $\alpha=5 \%$ ). Jika terdapat beda nyata dilakukan uji lanjut menggunakan uji BNJ pada taraf $5 \%$. Pilihan perlakuan terbaik digunakan metode Zeleny. Muffin non terigu perlakuan terbaik dari segi fisik dan organoleptik diperoleh pada perlakuan penggunaan kuning telur dan konsentrasi gel porang $2 \%$. Muffin tersebut memiliki kadar air sebesar $37.97 \%$, kadar protein sebesar $19.58 \%$, kadar lemak sebesar $17.20 \%$, kadar abu sebesar $1.53 \%$ dan kadar karbohidrat sebesar $36.67 \%$.
\end{abstract}

Kata Kunci: Muffin Non Terigu, Singkong, Kedelai Hitam, Glukomanan, Telur

\section{ABSTRACT}

The research is aimed to determine the effect of cassava and black soybean paste to the changes of physical, chemical and organoleptic of gluten free muffin. The experimenal design used was Factorial Randomized Block Design using two factors and repeated 3 times, so it obtained 24 experimental units. The first factor was the use of egg parts which consited of two levels (whole egg and yolk) while the second factor was the addition of porang gel concentration (0\%, 1\%, 2\%, 3\%). The data obtained was analyzed using ANOVA ( $\alpha=5 \%)$ to find out the difference between each treatments, followed by BNJ test with a $5 \%$ confidence interval. The best treatment selection was calculated using Zeleny method. The best treatment result was muffin with the addition of $2 \%$ porang gel and the use of yolk. The muffin has a water content of $37.97 \%$, protein content of $19.58 \%$, fat content of $17.30 \%$, ash content of $1.53 \%$ and carbohydrate content of $36.67 \%$.

Keywords: Non Gluten Muffin, Cassava, Black Soybean, Glucomannan, Egg

\section{PENDAHULUAN}

Muffin merupakan produk bakery jenis quick breads yang dibuat menggunakan agen pengembang kimia yang dapat bereaksi lebih cepat daripada ragi. Bahan dasar pembuatan muffin adalah tepung terigu. Namun, Indonesia merupakan salah satu negara yang tidak memungkinkan untuk dilakukan pembudidayaan gandum dikarenakan iklim yang kurang sesuai. Maka dari itu, untuk memenuhi kebutuhan konsumsi gandum, Indonesia melakukan impor dari negara-negara lain. Volume impor gandum dari tahun ke tahun semakin meningkat. Berdasarkan data APTINDO (2016), tingkat konsumsi gandum di Indonesia naik hingga 5.3\% menjadi 7.6 ton dimana pada tahun 2016 impor gandum hanya sebesar 8.3 juta ton. 
Salah satu upaya untuk mengatasi tingginya impor tepung terigu di Indonesia adalah mengembangkan produk berbasis gluten free yang berasal dari komoditas lokal Indonesia, yaitu singkong dan kedelai hitam. Singkong mengandung karbohidrat yang sangat tinggi, sehingga mampu menyediakan energi dalam jumlah yang cukup besar dan potensial untuk diolah menjadi produk pangan (Rukmana, 2002). Sedangkan kedelai hitam digunakan sebagai sumber utama protein nabati pada muffin non terigu. Kedelai hitam juga digunakan sebagai pembentuk cita rasa gurih karena mengandung asam amino glutamat yang lebih tinggi daripada kedelai kuning.

Namun pembuatan muffin menggunakan pasta singkong dan kedelai hitam tidak menghasilkan produk dengan karakter khas muffin komersial. Oleh karena itu diperlukan komponen tambahan yang dapat mempertahankan sifat-sifat muffin yaitu penambahan senyawa polimer pada adonan. Penggunaan senyawa polimer yang dibutuhkan ialah yang mampu meniru sifat viskoelastik dari gluten, dapat mengikat air sehingga bisa digunakan untuk memperbaiki karakter struktur, serta dapat memerangkap gas yang optimal sehingga mampu mengembangkan volume pengembangan (Gurkin, 2002). Salah satu jenis polimer yang dapat digunakan adalah protein telur dan gel porang. Gel porang mengandung glukomanan yang dapat mengikat dan mempertahankan air ketika proses baking sehingga membentuk tekstur empuk muffin dan mengembangkan adonan. Sedangkan fungsi penambahan telur adalah untuk memperbaiki tekstur, kenampakan warna, dan mempertahankan kelembaban produk muffin yang tidak menggunakan gluten. Oleh sebab itu akan dilakukan penelitian lebih lanjut untuk mengetahui pengaruh variasi konsentrasi gel porang (glukomanan) dan penggunaan berbagai bagian telur dalam pembuatan muffin non terigu. Sehingga dapat diperoleh konsentrasi gel porang dan penggunaan bagian telur yang tepat untuk menghasilkan produk muffin yang memiliki karakter sesuai.

\section{BAHAN DAN METODE}

\section{Bahan}

Bahan yang digunakan dalam pembuatan muffin meliputi singkong yang diperoleh di pasar Tawangmangu Malang, kedelai hitam yang diperoleh dari Balai Penelitian Kacang dan Umbi (BALITKABI) Malang, tepung porang yang diperoleh dari PT AMBICO, susu bubuk full cream (merk Indomilk), telur, gula pasir, minyak goreng (merk Filma) dan baking powder (merk Cendrawasih). Sedangkan bahan yang digunakan dalam analisis yaitu $\mathrm{H}_{2} \mathrm{SO}_{4}$ pekat, $\mathrm{NaOH}$, $\mathrm{H}_{2} \mathrm{BO}_{4}, \mathrm{HCl}(0.1 \mathrm{~N})$, metil red, petrolium eter, akuades, PP (phenoftalein) dan tablet Kjedahl.

\section{Alat}

Alat yang digunakan untuk pembuatan muffin yaitu baskom, pisau, ulekan, cobek, panci, spatula, kulkas (merk Elektrolux), sendok, plastik PP, mixer (merk Kirin), cetakan muffin, oven listrik (merk Kirin), kompor gas (merk Quantum), timbangan analitik, timbangan, dan kertas label. Sedangkan peralatan yang digunakan untuk pembuatan gel porang adalah sendok, pengaduk kaca, beaker glass, gelas ukur, kompor listrik, jar, plastik PE, dan autoklaf. Peralatan yang digunakan dalam analisis adalah timbangan analitik (Ohaus Pioneer), plastik, penggaris (merk Butterfly), color reader (merk Konica Micolta), tensile strength, soxhlet, destilator (merk Buchi), furnace, cawan porselen, desikator, bola hisap, penjepit, labu lemak, labu Kjeldahl, biuret, glassware (Merk Iwaki Pyrex) dan statip.

\section{Desain Penelitian}

Penelitian ini menggunakan metode yang digunakan adalah Rancangan Acak Kelompok (RAKF) dengan 2 faktor yaitu konsentrasi gel porang $(0 \%, 1 \%, 2 \%, 3 \%)$ dan bagian telur (telur utuh dan kuning telur) yang dilakukan dengan 3 kali ulangan, sehingga diperoleh 24 satuan percobaan. Data selanjutnya dianalisis dengan ANOVA menggunakan Minitab 16 dengan selang kepercayaan $95 \%$.

\section{Tahapan Penelitian}

Penelitian dilaksanakan dalam 2 tahap. Tahap pertama adalah pembuatan gel porang dan tahap kedua adalah pembuatan muffin non terigu. Tahapan penelitian dijabarkan sebagai berikut: 


\section{Pembuatan Gel Porang (Modifikasi Dwiyanti, 2015)}

Alat dan bahan disiapkan. Pertama, tepung porang ditimbang sebanyak 1 gram kemudian dilarutkan pada air sebanyak $50 \mathrm{ml}$ dengan suhu $25^{\circ} \mathrm{C}$. Setelah itu larutan tepung porang dimasukkan ke dalam jar kaca dan dilakukan pengadukan manual menggunakan pengaduk kaca selama 60 menit. Kemudian jar kaca ditutup hingga rapat dan dimasukkan dalam plastik PE besar lalu diikat dengan karet. Setelah itu jar yang sudah terbalut plastik dimasukkan ke dalam autoklaf untuk tahap sterilisasi.

\section{Pembuatan Muffin Non Terigu}

Alat dan bahan dipersiapkan. Pertama dilakukan pembuatan pasta singkong dengan cara dikupas kulitnya, dipotong kecil-kecil, dan dicuci hingga bersih. Kemudian singkong dikukus selama 30 menit lalu dibiarkan hingga mencapai suhu ruang. Setelah itu dimasukkan pada freezer selama 24 jam. Selanjutnya singkong dithawing dan dihaluskan dengan ulekan. Sedangkan pembuatan pasta kedelai hitam diawali dengan merendam kedelai pada air panas selama 30 menit, dikupas, kemudian dicuci hingga bersih. Selanjutnya direbus selama 10 menit dan dihaluskan menggunakan ulekan. Kemudian dilanjutkan dengan pembuatan muffin non terigu yaitu telur dan gula dikocok menggunakan whisk sampai berbusa, kemudian bahan kering (susu, baking powder, garam, dan vanili) dimasukkan dan diaduk menggunakan spatula. Kemudian pasta singkong, kedelai hitam, gel porang, dan minyak nabati dimasukkan dan diaduk menggunakan spatula. Setelah itu dicetak pada cup muffin sampai tiga perempat penuh dan dipanggan pada suhu $180^{\circ} \mathrm{C}$ selama 60 menit.

\section{Prosedur Analisis}

Analisis bahan baku dan analisis perlakuan terbaik meliputi analisis kadar air metode thermogravimetri (AOAC, 2005), kadar lemak metode Soxhlet (Sudarmaji, 1997), kadar protein metode Kjeldahl (AOAC, 2005), kadar abu (AOAC, 2005) dan kadar karbohidrat metode by difference (Winarno, 1986).

Analisis fisik produk muffin non terigu meliputi analisis volume pengembangan (Hartajanie dan Ranie, 2010), tekstur (kekerasan) ( Hartajanie dan Ranie, 2010), ukuran pori (Software Image) (Lin, 2014), warna L*, a+, b+ (color reader) (Yuwono dan Susanto, 1998), dan analisis organoleptik (uji hedonik dan uji skoring).

\section{HASIL DAN PEMBAHASAN}

\section{Analisis Bahan Baku}

Berdasarkan Tabel 1., kadar air pada pasta singkong dan kedelai hitam lebih tinggi daripada komoditas segar literatur. Perbedaan nilai kadar air ini disebabkan adanya proses pengukusan dan perebusan. Pengukusan dan perebusan menggunakan suhu yang tinggi akan menyebabkan ikatan antara komponen bahan seperti karbohidrat, lemak, dan protein akan pecah, sehingga air akan berikatan dengan bahan dan menyebabkan kadar air meningkat. Faktor lain yang berpengaruh yaitu kondisi lingkungan tanam yang berbeda, perbedaan umur panen serta kondisi penyimpanan setelah panen (Harnowo, et al. 2017).

Kadar karbohidrat pasta singkong lebih rendah daripada literatur. Hal ini disebabkan adanya faktor pencucian, pengukusan, dan penumbukan. Faktor pengolahan berpengaruh terhadap kandungan nutrisi bahan, terutama serat pangan. Faktor eskternal berupa kondisi tanah, cara penanaman, suhu tanam, kelembabab, dan kondisi pasca panen juga menyebabkan perbedaan karakteristik pada singkong (Wang, 2010). Sedangkan pada kedelai hitam perbedaan kadar karbohidrat disebabkan karena adanya proses perendaman (Suarti, 2013). 
Tabel 1. Data Hasil Analisis Bahan Baku Pasta Singkong dan pasta Kedelai Hitam dengan Literatur

\begin{tabular}{lcccc}
\hline \multirow{2}{*}{ Komponen } & \multicolumn{2}{c}{ Singkong } & \multicolumn{2}{c}{ Kedelai Hitam } \\
\cline { 2 - 5 } & $\begin{array}{c}\text { Pasta } \\
\text { Singkong }\end{array}$ & $\begin{array}{c}\text { Singkong } \\
\text { Segar }\end{array}$ & $\begin{array}{c}\text { Pasta Kedelai } \\
\text { Hitam* }\end{array}$ & $\begin{array}{c}\text { Kedelai } \\
\text { Hitam } \\
\text { Segar }^{\star *}\end{array}$ \\
\hline Kadar air (\%) & $67.09 \pm 0.06$ & 59.68 & $55.82 \pm 0.15$ & 9.72 \\
Kadar karbohidrat (\%) & $31.84 \pm 0.11$ & 38.06 & $18.22 \pm 0.59$ & 23.49 \\
Kadar protein (\%) & $0.51 \pm 0.04$ & 1.36 & $19.72 \pm 0.16$ & 42.17 \\
Kadar lemak (\%) & $0.14 \pm 0.03$ & 0.28 & $4.20 \pm 0.52$ & 18.29 \\
Kadar abu(\%) & $0.43 \pm 0.01$ & 1.5 & $2.06 \pm 0.07$ & 6.33 \\
\hline
\end{tabular}

Keterangan : 1) Setiap data hasil analisis merupakan rerata dari 3 ulangan \pm standar deviasi

${ }^{*}=$ Hasil analisis penelitian

${ }^{* *}=$ Literatur Singkong: USDA (2016)

${ }^{* *}=$ Literatur Kedelai Hitam: Ginting (2014)

Perbedaan kadar protein pasta singkong dan literatur disebabkan perbedaan komoditas yang dianalisis. Faktor eksternal meliputi kondisi tanam, lingkungan, iklim dan masa simpan berpengaruh terhadap kadar protein. Namun singkong juga merupakan komoditas dengan nilai protein yang rendah. Sedangkan pada kedelai hitam, perbedaan kadar protein disebabkan karena adanya proses perebusan yang menyebabkan denaturasi protein dan beberapa asam amino akan terlarut pada air dengan suhu yang tinggi (Sundari, 2015).

Kadar lemak pada singkong memang relatif rendah. Namun perbedaan antara pasta singkong dengan literatur singkong segar disebabkan karena pembuatan pasta membutuhkan proses pemanasan yang dapat menyebabkan komponen lemak pecah menjadi produk volatile sehingga berpengaruh terhadap pembentukan flavor. Sedangkan perbedaan kadar lemak pasta kedelai hitam dengan literatur disebabkan karena proses perendaman dan blanching pada biji yang menyebabkan terjadinya penetrasi air ke dalam benih sehingga lemak kedelai larut dalam air dan kadarnya menurun (Ranie et al, 2013). Perbedaan kadar abu dari kedua bahan disebabkan karena selama proses pengukusan dan perebusan, mineral dan abu akan menguap bersama uap air (Purnama, et al, 2011).

\section{Analisis Fisik}

Analisis fisik dilakukan menggunakan beberapa parameter meliputi analisis volume pengembangan, kekerasan (tekstur), ukuran pori dan warna crust dan crumb ( $\left.L^{*} . a+, b+\right)$. Data hasil analisis dapat dilihat pada Tabel 2.

Tabel 2. Hasil Analisis Volume Pengembangan, Kekerasan, Ukuran Pori

\begin{tabular}{lccc}
\hline $\begin{array}{c}\text { Konsentrasi Gel } \\
\text { Porang dan } \\
\text { Bagian Telur }\end{array}$ & $\begin{array}{c}\text { Rerata Volume } \\
\text { Pengembangan (\%) }\end{array}$ & $\begin{array}{c}\text { Rerata } \\
\text { Kekerasan } \\
\text { (Tekstur) }(\mathbf{N})\end{array}$ & $\begin{array}{c}\text { Rerata Ukuran } \\
\text { Pori }\left(\mathbf{m m}^{2}\right)\end{array}$ \\
\hline 0\% telur utuh & $46.14 \pm 0.71$ & $2.31 \pm 0.14$ & $1.15 \pm 0.60$ \\
0\% kuning telur & $42.98 \pm 0.56$ & $2.86 \pm 0.08$ & $0.76 \pm 0.13$ \\
1\% telur utuh & $49.07 \pm 0.46$ & $2.13 \pm 0.08$ & $1.49 \pm 0.24$ \\
1\% kuning telur & $46.10 \pm 0.61$ & $2.48 \pm 0.05$ & $0.91 \pm 0.12$ \\
2\% telur utuh & $54.97 \pm 0.77$ & $2.04 \pm 0.12$ & $1.52 \pm 0.94$ \\
2\% kuning telur & $52.83 \pm 1.35$ & $2.41 \pm 0.09$ & $1.16 \pm 0.12$ \\
3\% telur utuh & $57.12 \pm 1.32$ & $1.85 \pm 0.11$ & $1.78 \pm 0.45$ \\
3\% kuning telur & $55.36 \pm 0.89$ & $2.21 \pm 0.02$ & $1.31 \pm 0.16$ \\
\hline
\end{tabular}

Keterangan: Setiap data merupakan rerata dari 3 ulangan 


\subsection{Volume Pengembangan}

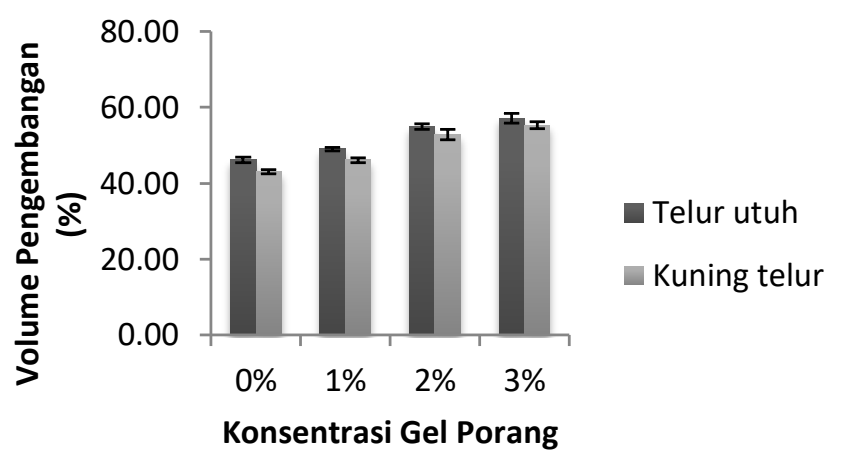

Gambar 1. Grafik Rerata Volume Pengembangan Akibat Penambahan Gel Porang dan Bagian Telur Yang Berbeda

Hasil analisis menunjukkan bahwa perlakuan penambahan konsentrasi gel porang dan bagian telur yang berbeda berpengaruh nyata terhadap volume pengembangan muffin non terigu. Semakin tinggi konsentrasi gel porang yang diberikan, maka volume pengembangan muffin akan semakin meningkat. Telur utuh juga berkontribusi dalam mengembangkan volume lebih tinggi daripada kuning telur. Nilai volume pengermbangan tertinggi diperoleh dari penambahan konsentrasi gel porang sebesar 3\% dengan jenis telur utuh.

Pengaruh penambahan konsentrasi gel porang terhadap volume pengembangan muffin non terigu berkaitan dengan sifat gel porang dapat meningkatan nilai Water Holding Capacity (WHC) sehingga mampu mengikat air pada adonan. Semakin tinggi konsentrasi glukomanan, maka akan semakin banyak air yang diikat ketika proses gelatinisasi saat pengovenan, hal ini akan menyebabkan volume adonan mengembang (Anggraeni dkk, 2014).

Penambahan bagian telur yang berbeda juga mempengaruhi volume pengembangan. Bagian telur utuh memiliki sifat mengembangkan adonan lebih tinggi dibandingkan kuning telur. Hal ini disebabkan karena telur utuh memiliki kandungan ovalbumin yang berkemampuan untuk menahan udara apabila dicampur dengan gula, sehingga membentuk produk yang ringan dan mengembang lebih baik daripada kuning telur. Selain itu adanya globulin pada putih telur juga berperan dalam membentuk dan menstabilkan busa dengan cara meningkatkan viskositas cairan dan menurunkan tegangan permukaan (Koswara, 2009). Sedangkan kuning telur hanya berfungsi sebagai emulsifier.

\subsection{Tekstur}

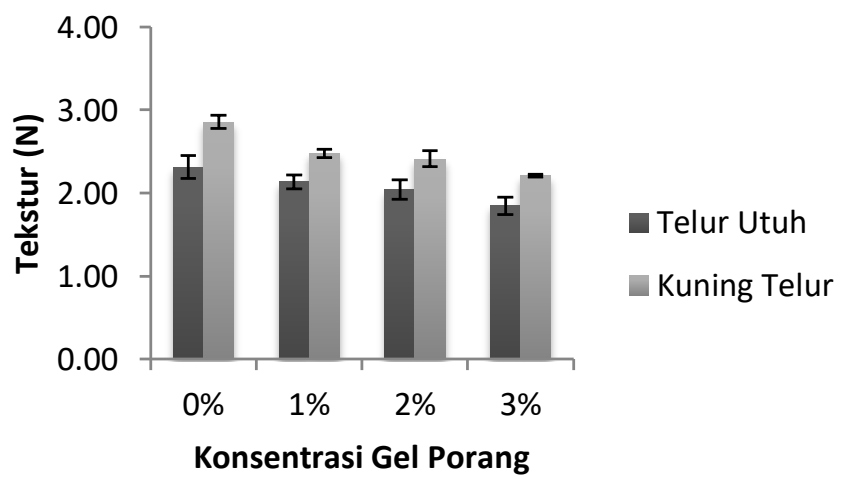

Gambar 2. Grafik Rerata Tekstur Akibat Penambahan Gel Porang dan Bagian Telur Yang Berbeda 
Hasil analisis menunjukkan bahwa perlakuan penambahan konsentrasi gel porang dan bagian telur yang berbeda berpengaruh nyata terhadap tekstur muffin non terigu. Semakin rendah konsentrasi gel porang yang diberikan, maka nilai tekstur muffin akan semakin tinggi. Kuning telur juga berkontribusi dalam meningkatkan nilai tekstur daripada telur utuh. Nilai tekstur muffin tertinggi diperoleh dari penambahan konsentrasi gel porang sebesar $0 \%$ dengan penggunaan kuning telur.

Adanya penambahan gel porang pada pembuatan muffin berpengaruh terhadap nilai tekstur produk dikarenakan gel porang mengandung glukomanan yang bersifat hidrofilik. Sifat hidrofilik tersebut menyebabkan glukomanan dapat mengikat air dan mempertahankan air tersebut di dalam adonan muffin ketika proses baking, sehingga air akan tetap di dalam dan mempertahankan tekstur muffin yang lembut. Sumarwoto (2007), menyatakan bahwa 1 gram glukomanan dapat menyerap $100 \mathrm{gr}$ air, yang menandakan jika adonan muffin akan memiliki tekstur moist karena kadar air yang tinggi.

Penggunaan telur utuh menyebabkan tekstur muffin non terigu yang dihasilkan akan semakin empuk karena telur membuat bahan makanan yang dipanggang lebih lembut, menciptakan tekstur ringan, dan tekstur crumb yang lembut (Munday et al, 2017). Sedangkan peran utama kuning telur adalah emulsifier yang menciptakan stabilisasi antar muka gas-air dan air-gas sehingga adonan lebih konsisten dan seragam (Soenardi, 2013). Lesitin yang berada pada kuning telur mampu membentuk sistem emulsi yang stabil dalam adonan cake sehingga mencegah kedua komponen untuk berpisah. Hal ini akan menimbulkan tekstur yang dibangun oleh kuning telur menjadi lebih kokoh dan homogen. Lipoprotein pada kuning telur juga mampu menstabilkan ekspansi sel-sel gas selama kenaikan suhu oven, yang sangat penting untuk mendapatkan kepadatan tekstur muffin yang tinggi (Deleu, 2015).

\subsection{Ukuran Pori}

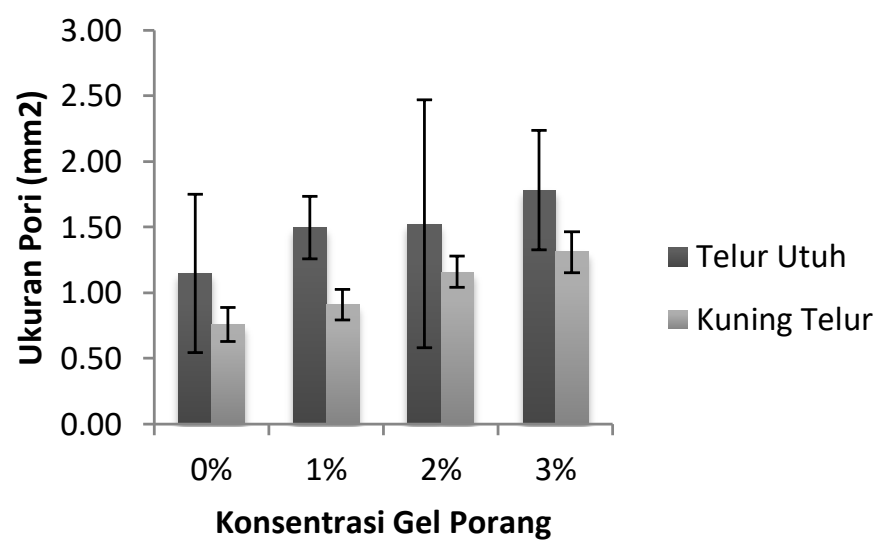

\section{Gambar 3. Grafik Rerata Ukuran Pori Akibat Penambahan Gel Porang dan Bagian Telur Yang Berbeda}

Hasil analisis menunjukkan bahwa perlakuan penambahan konsentrasi gel porang tidak berpengaruh nyata sedangkan penggunaan bagian telur yang berbeda berpengaruh nyata terhadap ukuran pori muffin non terigu. Telur utuh memberikan nilai ukuran pori yang lebih besar daripada kuning telur.

Telur memiliki peran dalam pembentukan struktur sel (pori) pada muffin. Telur utuh mengandung dua protein yang berperan dalam pembentukan struktur, yaitu albumin dan ovalbumin yang terdapat pada putih telur. Protein albumin apabila dikocok, mampu membentuk gelembung-gelembung udara yang stabil sehingga berperan dalam peningkatan volume pengembangan saat proses baking (Demirkol, 2007). Sedangkan ovalbumin akan terkoagulasi selama proses baking sehingga mampu membentuk jaringan yang resisten untuk terpisah ketika air menguap (Phillips et al, 1994). Proses koagulasi protein selama pembakaran tersebut akan menghasilkan pori yang lebih terbuka dan remah yang halus. Telur utuh mengandung lebih banyak kadar air sehingga mampu membentuk rongga pori yang lebih besar dan menyebabkan muffin yang dihasilkan memiliki tekstur yang ringan dan mengembang. Sedangkan bagian kuning telur memiliki peran sebagai penstabil (emulsifier) 
pada tahapan tersebut. Lipoprotein yang terkandung pada kuning telur dapat membantu untuk menstabilkan ekspansi sel udara saat proses pemanggangan, sehingga dapat membentuk struktur yang lebih kokoh. Selain itu keberadaan lemak tinggi pada kuning telur dapat menjaga stabilitas gelembung gas sehingga struktur dan pori cake dapat terbentuk dengan baik selama pemanggangan serta menghasilkan crumb yang lembut (Cauvain dan Young, 2006).

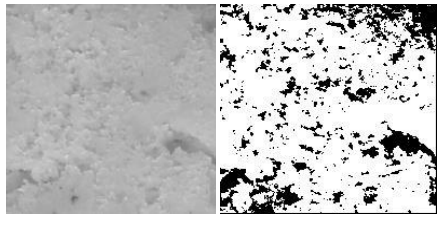

$0 \%$ Telur Utuh

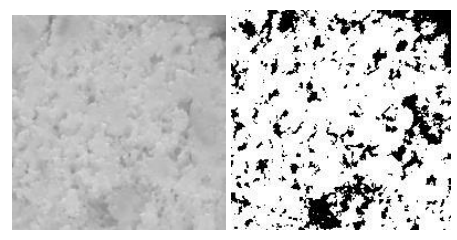

$1 \%$ Telur Utuh

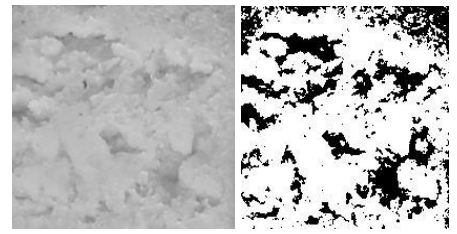

$2 \%$ Telur Utuh

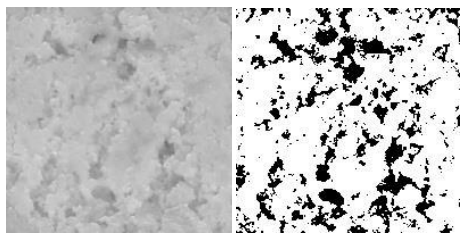

$3 \%$ Telur Utuh

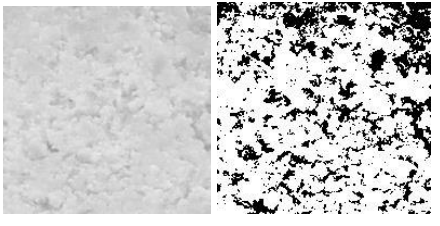

$0 \%$ Kuning

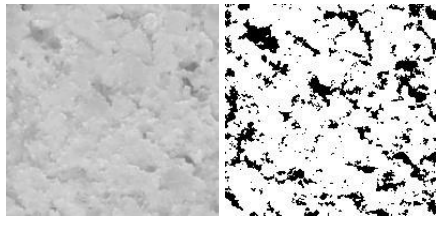

$1 \%$ Kuning

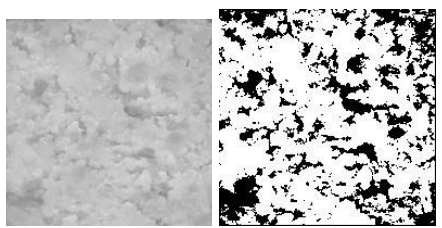

$2 \%$ Kuning

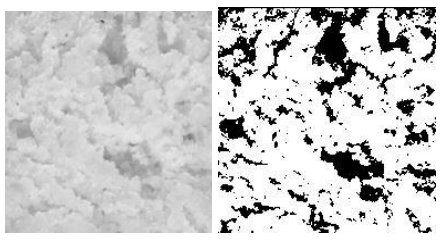

$3 \%$ Kuning

Gambar 4. Hasil Analisis Porositas Muffin Non Terigu Akibat Penambahan Gel Porang dan Bagian Telur yang Berbeda

\section{Warna}

Hasil analisis menunjukkan bahwa penggunaan bagian telur yang berbeda berpengaruh nyata terhadap kecerahan crust dan crumb, namun penambahan konsentrasi gel porang tidak berpengaruh nyata pada nilai kecerahan crust dan crumb.

Pembentukkan nilai warna (kecerahan, kemerahan, dan kekuningan) pada crust dan crumb muffin non terigu dapat disebabkan karena adanya penambahan kuning telur pada adonan. Kuning telur mengandung zat warna (pigmen) yang berupa karotenoid. Karotenoid yaitu pigmen alami pada kuning telur yang yang memiliki rentang warna dari kuning pucat hingga kuning oranye gelap. Telur banyak mengandung karotenoid berupa xantofil, yaitu molekul karotenoid yang berupa kumpulan hidroxy (Stadelman, dan Cotteril, 1997). Warna crust dan crumb muffin dengan penggunaan telur utuh dalam proses pembuatannya cenderung kurang terang, tidak terlalu kekuningan dan kemerahan apabila dibandingkan dengan perlakuan kuning telur. Hal ini diduga karena adanya kandungan protein yang lebih tinggi pada telur utuh. Protein telur utuh yang lebih tinggi akan menyumbangkan asam amino yang lebih banyak dan selanjutnya bereaksi secara non enzimatis dengan gula pereduksi pada saat proses pemanggangan (Reaksi Maillard) (Surya, 2008). 
Tabel 3. Hasil Analisis Warna kecerahan (L), Kemerahan (a+) dan Kekuningan (b+) pada Crust dan Crumb

\begin{tabular}{|c|c|c|c|c|c|c|c|}
\hline \multicolumn{5}{|c|}{ Crust } & \multicolumn{3}{|c|}{ Crumb } \\
\hline 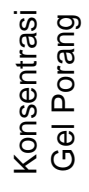 & 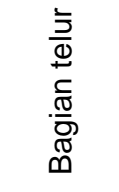 & 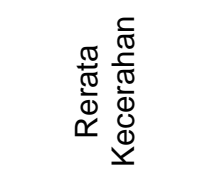 & 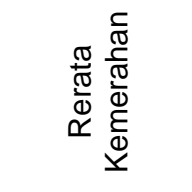 & 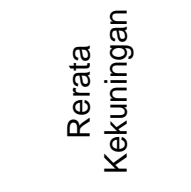 & 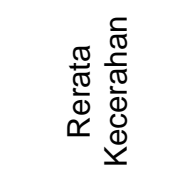 & 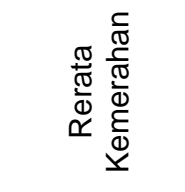 & 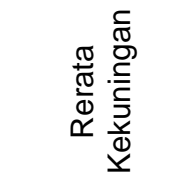 \\
\hline $0 \%$ & Utuh & $61.28 \pm 2.06$ & $6,76 \pm 0.84$ & $32.81 \pm 1.40$ & $65.78 \pm 1.46$ & $-0.86 \pm 0.14$ & $33.93 \pm 1.53$ \\
\hline $0 \%$ & Kuning & $64.63 \pm 0.51$ & $10.07 \pm 0.47$ & $34.88 \pm 0.71$ & $66.91 \pm 1.04$ & $0.47 \pm 0.91$ & $35.16 \pm 1.32$ \\
\hline $1 \%$ & Utuh & $60.98 \pm 2.07$ & $6.95 \pm 0.80$ & $31.59 \pm 1.24$ & $65.06 \pm 0.56$ & $-0.71 \pm 0.51$ & $31.69 \pm 2.14$ \\
\hline $1 \%$ & Kuning & $63.91 \pm 1.07$ & $9.63 \pm 2.39$ & $33.37 \pm 1.10$ & $66.08 \pm 0.31$ & $0.20 \pm 0.36$ & $36.52 \pm 0.79$ \\
\hline $2 \%$ & Utuh & $60.65 \pm 1.88$ & $7.37 \pm 1.11$ & $32.40 \pm 1,59$ & $65.15 \pm 1.07$ & $-1.74 \pm 1.02$ & $32.88 \pm 1.62$ \\
\hline $2 \%$ & Kuning & $63.79 \pm 1.04$ & $11.24 \pm 0.54$ & $34.77 \pm 2.09$ & $66.35 \pm 0.65$ & $0.51 \pm 0.36$ & $36.72 \pm 1.09$ \\
\hline $3 \%$ & Utuh & $59.96 \pm 2.50$ & $7.98 \pm 0.54$ & $30.77 \pm 2.32$ & $65.43 \pm 1.20$ & $-0.78 \pm 0.50$ & $31.23 \pm 0.99$ \\
\hline $3 \%$ & Kuning & $63.29 \pm 0.87$ & $11.37 \pm 0.45$ & $33.79 \pm 2.19$ & $66.36 \pm 0.48$ & $0.42 \pm 0.16$ & $36.23 \pm 0.19$ \\
\hline
\end{tabular}

Keterangan:Setiap data merupakan rerata dari 3 ulangan

Crust muffin cenderung memiliki warna lebih coklat daripada crumb dikarenakan adanya perubahan kimia berupa karamelisasi dan reaksi Maillard antara protein dan gula pereduksi. Crust tebentuk ketika temperatur pembakaran mencapai suhu di atas $100^{\circ} \mathrm{C}$. Adanya kedua reaksi kimia tersebut akan menurunkan aktivitas air pada bahan sehingga terjadi pengerasan pada kerak (crust) dan perubahan warna kerak menjadi coklat keemasan (Smith and Hui, 2004). Sedangkan crumb memiliki warna yang lebih cerah karena tidak terpapar langsung dengan temperatur tinggi saat proses baking.

Gel porang tidak berpengaruh nyata pada nilai warna (kecerahan, kekuningan, dan kemerahan) karena ditambahkan dalam bentuk gel. Hal ini sesuai dengan literatur (Departemen Pertanian, 2009) yang menyatakan bahwa glukomanan dapat membentuk lapisan tipis film yang mempunyai sifat transparan atau tidak berwarna ketika larut dalam air.

\section{Analisis Organoleptik}

Uji organoleptik bertujuan untuk mengetahui tingkat penerimaan konsumen terhadap suatu produk yang dihasilkan baik dari segi penampilan, warna, aroma, tekstur, dan rasa. Uji organoleptik dilakukan dalam dua metode yaitu hedonik dan skoring dengan jumlah panelis sebanyak 45 orang.

Uji hedonik merupakan uji penerimaan produk berdasarkan tingkat kesukaan panelis. Tingkat kesukaan panelis pada uji hedonik dijabarkan dalam bentuk skala dari 1-5 (sangat tidak suka, tidak suka, agak suka, suka, sangat suka). Sedangkan uji skoring merupakan jenis pengujian skalar yang dinyatakan dalam skala numerik (Susiwi, 2009). Uji skoring digunakan untuk menilai intensitas suatu produk dengan susunan meningkat maupun menurun.

Berdasarkan hasil analisis uji hedonik dan skoring, diketahui bahwa panelis cenderung menyukai produk muffin non terigu dengan perlakuan penambahan gel porang konsentrasi $2 \%$ dan penggunaan kuning telur. Hal ini diduga karena penggunaan gel porang dapat membentuk tekstur yang lebih lembut. Glukomanan memiliki sifat hidrofilik yang dapat mempertahankan air ketika proses baking sehingga membentuk tekstur yang moist ketika digigit. Selain itu penambahan kuning telur berperan dalam pembentukkan tekstur yang lebih kokoh karena kandungan lipoprotein yang dapat menstabilkan ekspansi gas ketika pengovenan. Adanya kandungan pigmen karotenoid berupa xantofil pada kuning telur juga dapat memberikan warna yang lebih menarik para panelis.

\section{Analisis Perlakuan Terbaik}

Perlakuan terbaik pada muffin non terigu didapatkan dari perhitungan metode Multiple Attribute Zeleny. Penentuan perlakuan terbaik ini berdasarkan dari data uji fisik serta 
organoleptik. Hasil perlakuan terbaik yang diperoleh yaitu muffin non terigu dengan perlakuan penambahan konsentrasi glukomanan sebesar $2 \%$ dan penggunaan bagian kuning telur

Tabel 4. Hasil Analisis Kimia Proksimat

\begin{tabular}{ccc}
\hline $\begin{array}{c}\text { Parameter kimia } \\
(\% \mathbf{b} / \mathbf{b})\end{array}$ & $\begin{array}{c}\text { Perlakuan terbaik } \\
\text { muffin non terigu }\end{array}$ & $\begin{array}{c}\text { Muffin Terigu } \\
\text { Komersial }\end{array}$ \\
\hline Air & 37.97 & 24.10 \\
Protein & 6.53 & 4.85 \\
Lemak & 17.30 & 23.04 \\
Abu & 1.53 & 1.44 \\
Karbohidrat & 36.67 & 46.57 \\
\hline Keterangan: & Setiap data merupakan rerata dari 3 ulangan
\end{tabular}

Berdasarkan analisis proksimat, diketahui bahwa kadar air muffin perlakuan terbaik lebih tinggi daripada muffin komersial. Perbedaan kadar air diduga karena perbedaan bahan yang digunakan dan proses pengolahan. Adanya proses pengukusan pada bahan baku dapat meningkatkan kadar air karena terjadi penyerapan uap air selama pemanasan untuk proses gelatinisasi. Selain itu, adanya penambahan gel porang yang mengandung glukomanan juga mampu mengikat air pada muffin non terigu sehingga mempertahankan kelembaban muffin.

Kadar protein pada muffin non terigu perlakuan terbaik adalah sebesar $6.53 \%$. Kadar protein muffin ini lebih tinggi daripada muffin terigu komersial (4.85\%). Perbedaan kadar protein ini disebabkan karena penggunaan kedelai hitam yang berperan sebagai salah satu sumber protein nabati. Selain itu, penggunaan kuning telur juga berpengaruh terhadap kadar protein muffin. Walaupun bukan sumber protein utama dalam telur, namun kuning telur mengandung protein sebesar 15-16\% (Balai Penelitian Ternak, 2006).

Kadar lemak pada muffin non terigu perlakuan terbaik adalah sebesar $17.30 \%$. Kadar lemak muffin ini lebih rendah daripada muffin terigu komersial (23.04\%). Kandungan lemak muffin non terigu perlakuan terbaik lebih rendah daripada muffin terigu komersial disebabkan karena adanya penambahan gel porang. Glukomanan dapat menurunkan kadar kolesterol total dan memiliki sifat sebagai serat yang mampu menyerap air sehingga penambahannya dalam bahan makanan dapat membuat produk memiliki kandungan lemak yang rendah (Bekti, 2014).

Kadar abu pada muffin non terigu perlakuan terbaik adalah sebesar $1.53 \%$. Kadar abu muffin ini tidak berbeda jauh dengan muffin terigu komersial (1.44\%). Faktor utama yang menyebabkan selisih pada kadar abu adalah bahan yang digunakan berbeda.

Kadar karbohidrat pada muffin non teriigu perlakuan terbaik adalah sebesar $36.67 \%$. Kadar karbohidrat muffin ini lebih rendah daripada muffin terigu komersial $(46.57 \%)$. Perbedaan kadar karbohidrat pada muffin non terigu disebabkan karena penggunaan bahan baku pasta singkong yang memiliki kadar karbohidrat sebesar 34.7\% (Depkes RI, 1981), kadar ini lebih rendah daripada tepung terigu (72.3\%) (Daftar Komposisi Bahan Makanan, 2000).

\section{SIMPULAN}

Perlakuan penambahan ge/porang pada konsentrasi tertentu dan penggunaan bagian telur yang berbeda memberikan pengaruh nyata terhadap seluruh karakteristik organoleptik muffin non terigu yang dihasilkan. Pada karakteristik fisik, perbedaan perlakuan konsentrasi gel porang hanya memberikan pengaruh nyata $(\alpha=0.05)$ terhadap tekstur dan volume pengembangan. Sedangkan penambahan bagian telur (utuh dan kuning telur) memberikan pengaruh yang berbeda nyata $(\alpha=0.05)$ terhadap seluruh parameter fisik.

Berdasarkan karakteristik fisik dan organoleptik yang diuji, didapatkan perlakuan terbaik dari hasil perhitungan metode Zeleny yaitu perlakuan dengan konsentrasi gel porang (2\%) dan penambahan bagian kuning telur. Perlakuan terbaik memiliki kadar air sebesar $37.97 \%$, kadar protein $6.53 \%$, kadar lemak $17.30 \%$, kadar abu $1.53 \%$, dan kadar karbohidrat $36.67 \%$. 


\section{DAFTAR PUSTAKA}

Asosiasi Produsen Tepung Terigu Indonesia (APTINDO). 2016. Indonesia Wheat Flour Consumption and Growth. <http://aptindo.or.id. >. Tanggal akses: 23 Januari 2018.

Cauvain, S.P and L.S. Young. 2006. Baked Products: Science, Technology and Practice. Blackwell Publishing. England.

Deleu, Lomme. 2017. Functional Roles of Egg White and Yolk in Pound Cake Making. University of Leuven. Belgia.

Depkes RI. 2005. Daftar Komposisi Bahan Makanan. Depkes RI. Jakarta.

Gurkin, S. 2002. Hydrocolloids- Ingredients That Add Flexibility to Tortilla Processing.Cereal Foods World, 47: 41-43.

Harnowo, D., E. Ginting, M. Adie, Ratnaningsih. 2017. Sifat Fisikokimia dan Kandungan Serat Pangan Galur-Galur Harapan Kedelai. Jurnal Penelitian Pascapanen Pertanian. 14:1, 35-45.

Hartajanie, L., dan Rhanie A. 2010. Peningkatan Kualitas Roti Non Terigu Berbasis Tepung Ubi Kayu (Menihot utilissima) Menggunakan Hidrokoloid dan Enzim. Tesis. Universitas Katolik Soegijapranata. Semarang.

Koswara, S. 2009. Teknologi Pengolahan Telur (Teori dan Praktek). <http://eBookPangan.com>. Tanggal akses: 20 Januari 2018.

Munday, E., L. Werblin, and K. Deno. 2017. Blueberry Muffin Application Research: Comparing the Functionality of Eggs to Egg Replacers in Blueberry Muffin Formulations. CuliNex. USA.

Phillips, L.G. D.M. Whitehead, and J.E. Kinsella. 1994. Structure-Function Properties of Food Proteins. Academic Press. San Diego.

Ranie, H., Zulfahmi, dan Yatim R. Widodo. 2013. Optimasi Proses Pembuatan Bubuk (Tepung) Kedelai. Jurnal Penelitian Pertanian Terapan 13:3, 188-196.

Rukmana, Rahmat. 2002. Usaha Tani Ubi Kayu. Penerbit Kanisius. Jogjakarta

Smith J.S. and Y.H. Hui. 2004. Food Processing : Principles And Applications 1st Ed. Blackwell Publishing Professional. USA.

Soenardi, Tuti. 2013. Teori Dasar Kuliner. PT. Gramedia Pustaka Utama. Jakarta.

Stadelman, W. J. and O. J. Cotterill. 1997. Egg Science and Technology 4th Edition. Haworth Press Inc. New York.

Suarti, Budi, et al. 2013. Pembuatan Pati dari Biji Durian melalui Penambahan Natrium Metabisulfit dan Lama Perendaman. Jurnal Agrium. 18(1): 69-78.

Sudarmadji. S., B. Haryono, dan Suhardi. 1996. Analisis Bahan Makanan dan Pertanian. Liberty Yogyakarta. Yogyakarta.

Sumarwoto. 2007. Review: Kandungan Mannan Pada Tanaman lles-lles (Amorphophallus muelleri Blume). Bioteknologi..4(1): 28-32

Sundari, D., Almasyhuri, dan A. Lamid. 2015. Pengaruh Proses Pemasakan Terhadap Komposisi Zat Gizi Bahan Pangan Sumber Protein. Media Litbangkes, 25:4, 235242.

Surya, Catrien. 2008. Reaksi Maillard Pada Produk Pangan. Institut Pertanian Bogor. Bogor.

Wang, Guang. 2007. Functionality of Egg Yolk Lecithin and Protein and Functionality Enhacement of Protein by Controlled Enzymatic Hydrolysis. Iowa State University. USA.

Winarno, F.G. 1992. Kimia Pangan dan Gizi. PT. Gramedia Pustaka Utama. Jakarta.

Yuwono, Sudarminto S. dan T. Susanto. 1998. Pengujian Fisik Pangan. Universitas Brawijaya. Malang. 